\title{
Risk Factors for Blood Loss Following Total Knee Arthroplasty: How Far is Left to Go?
}

\author{
Mansour Abolghasemian ${ }^{1, *}$ \\ ${ }^{1}$ Bone and Joint Reconstruction Research Center, Shafa Orthopedic Hospital, Iran University Of Medical Sciences, Tehran, IR Iran \\ ${ }^{*}$ Corresponding author: Mansour Abolghasemian, Bone and Joint Reconstruction Research Center, Shafa Orthopedic Hospital, Iran University Of Medical Sciences, Tehran, IR Iran. \\ Tel: +98-2133542007, Fax: +98-2133542020, E-mail: mabolghasemian@gmail.com
}

Received: April 21, 2015; Revised: May 16, 2015; Accepted: May 28, 2015

\section{Introduction}

Summary of "Risk Factors for Blood Loss Following Total Knee Arthroplasty” by Moghtadaei and Shahoseini (1).

\section{Summary}

The authors have reported on the prospective measurements of intra- and post-operative blood loss of 96 total knee arthroplasty cases and have analyzed the relationship between these values and demographical factors of the series. Mean intraoperative blood loss and postoperative drainage were determined to be $147.1 \pm 97.4 \mathrm{~mL}$ and 494.4 $\pm 188.1 \mathrm{~mL}$, respectively. Male and obese patients had significantly higher intraoperative blood loss, whereas male sex and older age were associated with a greater drop in hemoglobin ( $\mathrm{Hb})$, on the first postoperative day. No predictors of the need for transfusion were found.

\section{Discussion}

Although there are numerous studies of the role of patient and surgical factors on the amount of bone loss in TKA, they are not uniform in their conclusions $(2,3)$. This has been commented by the authors. The prospective nature of this study makes it more reliable. However, there are several limitations. The probable perioperative use of antifibrinolytic agents (i.e. tranexamic acid) has not been commented. This would have important implications on the findings. The $\mathrm{Hb}$ measurements have not been used in the blood loss calculations and have been reported as separate values. The amount of transfusion has not been considered for each individual. This has partly caused the inability to interpret the changes in $\mathrm{Hb}$ after the first day and has confounded the statistical evaluation of factors correlated with $\mathrm{Hb}$ changes.

The reported average amount of whole blood loss, intra- and post-operative, in this study is of $642 \mathrm{~mL}(147.1$ $+494.4)$. This is a considerably lesser amount than reported in literature. It is now evident that the amount of blood loss during a surgery is not confined to intraoperative estimations and postoperative drainage, as the most significant part of bleeding is hidden blood that distributes to local tissues $(4,5)$. Park et al. (6) reported a mean total blood loss of $2181.4 \mathrm{~mL}$ for primary total knee arthroplasty. Measurements had been performed using a previously validated formula that is now being used as standard practice for measuring blood loss, due to surgical procedures (7). This was also mentioned by the authors of the present study and its usage for calculations would be quite beneficial.

In summary, this study was valuable as it has added evidence to our perception of the risk factors of blood loss during total knee arthroplasty. However, it is necessary to further investigate to reach a perfect understanding of the process.

\section{References}

1. Moghtadaei M, Shahoseini GR. Risk Factors for Blood Loss Following Total Knee Arthroplasty. Shafa Ortho J 2014;1(4):24629.

2. Mesa-Ramos F, Mesa-Ramos M, Maquieira-Canosa C, Carpintero P. Predictors for blood transfusion following total knee arthroplasty: a prospective randomised study. Acta Orthop Belg. 2008;74(1):83-9.

3. Ogbemudia AE, Yee SY, MacPherson GJ, Manson LM, Breusch SJ. Preoperative predictors for allogenic blood transfusion in hip and knee arthroplasty for rheumatoid arthritis. Arch Orthop Trauma Surg. 2013;133(9):1315-20.

4. Sehat KR, Evans RL, Newman JH. Hidden blood loss following hip and knee arthroplasty. Correct management of blood loss should take hidden loss into account.J Bone Joint Surg Br. 2004;86(4):561-5.

5. Sehat KR, Evans R, Newman JH. How much blood is really lost in total knee arthroplasty?. Correct blood loss management should take hidden loss into account. Knee. 2000;7(3):151-5.

6. Park JH, Rasouli MR, Mortazavi SM, Tokarski AT, Maltenfort MG Parvizi J. Predictors of perioperative blood loss in total joint arthroplasty. J Bone Joint Surg Am. 2013;95(19):1777-83.

7. Rosencher N, Kerkkamp HE, Macheras G, Munuera LM, Menichella G, Barton DM, et al. Orthopedic Surgery Transfusion Hemoglobin European Overview (OSTHEO) study: blood management in elective knee and hip arthroplasty in Europe. Transfusion. 2003;43(4):459-69. 